\title{
Myths of Primitiveness: A Barthean Interpretation of Rhetorical Devices in Early Jazz Criticism
}

\author{
Claudia Alonso Recarte \\ University of Valencia \\ Claudia.Alonso@uv.es
}

\begin{abstract}
Ever since jazz began to make an impact in white aesthetic culture in the late 1910s and 1920s, critics, regardless of whether they celebrated or condemned the music, enmeshed their discourse with images of exoticism, noble savageness, and racial brutishness. As Jazz Studies emerged as an academic discipline, scholars have shown increasing interest in exposing these images in order to illustrate the pervading racist sentiment inscribed within white perception of the jazz idiom and also to establish the connections between jazz and the modernist obsession with primitivism. The aim of this paper is to contribute further study to the intricacies of primitivism through a close examination of the rhetorical devices enabling the subsistence and efficiency of the white supremacy's mystification of jazz. In this way, we may better comprehend how the primitivist construct is not a matter of an ideology's conglomeration of superficial images, nor of mere associations between the music and rituals. These features are certainly operative, but by approaching the metaliguistic techniques implicit in what Roland Barthes calls the bourgeois myth, jazz primitiveness can be conceived as an act of colonization that begins and is self-nurtured by patterns of speech.
\end{abstract}

Primitivism has been a controversial topic in jazz ever since the music began to germinate within cultivated European social circles and American white traditionalist society in the mid-1910s. From allegations of bestiality and the threat of a plaguing 
immorality, to descriptions of noble savageness and tantalizing exoticism, the transnational white hegemony was anything but indifferent to the powerful jazz idiom that was colonizing traditional forms of entertainment and escapism, and to which new generations seemed to be magnetically driven to. As postcolonial jazz studies developed as a self-conscious field of research from the 1960s onwards, the interpretation of primitivism in jazz history acquired increasing relevance for the examination of how racial identity is negotiated within aesthetic expression. The aim of this paper is to return once more to the written evidence of early jazz writing by whites in America and in Europe to attend to the actual linguistic devices that were commonly used to discursively control and subdue jazz. The contagiousness of the music was met by an act of counter-colonization in the hands of white critics, one which would mark the received image of jazz for decades with stereotypes and other racial assumptions. In order to maintain the notion of linguistic and meta-linguistic forms of imperialism, I will specifically attend to the rhetorical devices of mystification presented by Roland Barthes in his seminal study, Mythologies (1957). Although initially a Barthean reading of discursive techniques may strike as outdated, his exclusive insight into the tendentious manipulation of language-and by extension, reality-of the bourgeoisie through the exploitation of preferential rhetorical figures is useful to understand that the triumph of primitivist stereotypes and other denigrating images associated to black music answers to a carefully calculated speech pattern. Today's grand jazz narrative authoritatively recounts how in the beginning jazz was berated, castigated, and censured by a white society that was incapable of overcoming neither racism nor the elitism implicit in high art standards. Although this grand narrative has certainly been polished and simplified to satisfy the requirements demanded by any canonical construction, the truth of its claim is undeniable, as countless scholars who have dedicated their research to resuscitating documents, photographs, biographical sketches, and recordings with primitivist tinges have shown. What a Barthean interpretation of such evidence provides is a deciphering of the speech elements involved in primitivist discourse to establish the connections between myth and its underlying intentionality. In other words, rather than accepting the primitivist claim as an assumption and automatically positioning it as a motif of jazz history, this paper explores the intricacies that propelled the myth so effectively in the widespread perception of the music. The primitivist myth, I argue, is more than a conglomeration of images evoking African settings, bulging eyes, black skin, screeching notes, and frenetic dancing; these metonymies of white perception of negritude are divisible into identifiable rhetorical devices which answer to the overall purpose of bourgeois myth: the metalinguistic colonization of concepts through a deprivation of their history.

I.

It is in early developments of jazz criticism where scholars have identified the most salient tendencies to render the idiom as a primitive form of expression. Although the first jazz histories did not appear until the 1930s, numerous press accounts about 
personal responses to the music were prevalent since the late 1910s. Jazz writing, which was foremost an endeavor carried out by white Europeans and Americans, appeared to revolve around either the enthusiastic celebration of the aesthetic or around sentiments of loathing revulsion. Milder considerations stemming from white audiences were also numerous; however, more radicalized arguments either in favor or in disagreement with the idiom appear to have been more common. Neil Leonard's Jazz and the White Americans (1962), which picked up on Morroe Berger's acclaimed essay "Jazz: Resistance to the Diffusion of a Culture Pattern" (1947), became the leading work to closely evaluate the propensity with which jazz writing from the late 1910s to the late 1930s followed certain stereotypical patterns. Under a quasi-anthropological scope, Leonard chronologically follows the path by which jazz crossed from being a liminal art neglected by white traditionalists to becoming accepted thanks to the immersion of white composers and musicians in the less offensive movement of symphonic jazz, and a decade later, the swing era. Leonard collects countless references that preclude the intense sense of primitivism that white audiences felt permeated jazz, and analyzes the cultural reasons why aesthetic miscegenation presented a threat for white society. Ted Gioia's collection of essays, The Imperfect Art (1988), was another precursor in the primitivist debate. Gioia established the noble savage figure as a central motif in the writing of early jazz enthusiasts, and searched for the rootedness of the image as far back as sixteenth-century France and Montaigne's Des Canniballes. According to Gioia, the 'founding fathers' of jazz writing (Hugues Panassié, Charles Delauney, and Robert Goffin) expressed their fascination towards the music through passages that echoed imperialist condescendence of the racial 'other,' and ascertained that such tendencies were still visible in some characterizations of contemporary musicians such as Ornette Coleman. In 1991, John Gennari's "Jazz Criticism: Its Development and Ideologies," returned once more to the primitivist tendencies of the first jazz critics to point how the nascent narrative of the of the jazz canon (which began to crystallize around the 1980s), agglutinated and naturalized the transition between the antagonistic positions frequently held by jazz critics from the 1930s to the present.

A close examination of the evolution of the primitivist issue reveals that the discussion has slowly turned from historiography to either one of interdisciplinary interest or to one where the shared, canonical jazz narrative is questioned. A prime example of the first tendency is Alfred Appel's Jazz Modernism (2002), where the author poetically links the art of Louis Armstrong, Fats Waller, and Duke Ellington to Joyce's stream of consciousness and representative primitive pieces of Matisse and Picasso. Refraining from constructing an argument based on the application of any solid theory, Appel nonetheless presents a collage of images and literary excerpts which are connected to stylistic choices that these musicians made in some of their recordings, suggesting the universality of modernist obsession with experimentation whilst in celebration of a once existent natural code of conduct untainted by moral and social dialectics. Randall Sandke's recent scholarly work, Where the Dark and the Light Folks Meet (2010), on the other hand, provides a welcome approach to the revision of how race relations are construed in the current jazz canon, which for the last decade has been 
increasingly institutionalized through the politics practiced by Jazz at the Lincoln Center and its director and active spokesman, Wynton Marsalis. What is innovative about Sandke's work is that although he admits that to refute the widespread image of jazz musicians as primitive creatures until practically the emergence of bop would be nonsensical, he brings evidence to show cases in which race relations developed differently. Through a meticulous revision of documents of different periods in jazz history, Sandke suggests that there were numerous cases in which musicians were treated respectfully or as equals. Sandke is not attempting to deny the racism that was inherent to the jazz scene; what he challenges is the artificiality of the canon and its biased endeavor to reduce to pure antinomies the complex dynamics of race relations.

These are just a few of the numerous pieces that have approached jazz primitivism as a subject for analysis and that have been crucial for not only the salvaging of invaluable accounts that had been abandoned to oblivion, but for the establishment-and subsequent challenging-of the jazz history canon. There remain, nonetheless, significant crevices from which to further comprehend the dynamics involved in the construction of jazz primitivism, particularly at a linguistic level.

Before venturing into these mystifying techniques, however, let us first attend to the basic academic context into which jazz emerged and consider how it enabled primitive images. The process of molding and defining race is none other than the process by which white supremacy establishes and limits its relationship to otherness, that is, the process of 'othering.' Indeed, the advent of modern fascination with primitiveness can be traced as far back as Darwin's The Origin of Species By Means of Natural Selection (1859). Darwin postulated the propagation and survival of the fittest within the inevitability of evolution, suggesting along the way the ancestral bonds between man and animal. Nature was organically active, not static, cyclically repeating itself with no other purpose than to perfect the possibility of the survival of certain species. History and tradition, therefore, were nothing less than an illusion of rationalism; the narrative of the past did not delineate a single line towards progression but intermittently mapped a circle where beginning and end overlapped. If there was any promise of progress, it was to be attributed to natural forces, not to rationalism or spiritual zeal. Perfection of the species was based quantitatively on the preciseness and skill with which the group adapted to the environment, no longer on the Cartesian separation between soul and matter or the biblical justification to manipulate and transform nature to one's will. Fin-de-siècle literature apocalyptically fantasized about the dystopian horrors of evolution (H.G. Wells) and about the otherness slumbering within (Robert Louis Stevenson). During the prime of modernism, the racial 'other' spawned as an aesthetic motif. The avant-gardes' experimentation with form and content in an effort to reproduce subjectivity and the absurd, tragic, or nihilist connections between man and history found in African and Oceanic art the necessary symbols to address the futility of progress. In this vortex of creative output, jazz emerged as the quintessential music of man's primitive past, an anachronism signifying the cyclic, spatial nature of time where purity and innocence contested the atrophied sense of the self weighing heavily over humanity's shoulders. In the same way that race 
was experienced as a social construct, so did jazz, as a signifier of race, bear the association with certain mental capacities and instinctive urges.

Gioia (1988) has pointed out that Delauney and Goffin were highly influenced by Apollinaire, one of the aesthetic forbearers of modern primitivism. Apollinaire was responsible for the cubist manifesto "On Painting" (1913), where the aims and motives behind the movement were collected. Among other things, he divided cubism into four distinct forms of expression: scientific cubism, physical cubism, orphic cubism, and instinctive cubism. It is in this last category where primitivist inspiration becomes more evident: "Instinctive cubism is the art of painting new compositions taken not from reality as it is seen, but as it is suggested to the artist by instinct and intuition... Instinctive artists lack lucidity and an artistic creed" (Apollinaire, 2004: 26), he wrote. This unmediated automatism between the instinctual and the artistic product could be used as either a reason to condemn or to admire jazz. For these early pro-jazz writers, the relationship between musician and instrument was based on a certain state of trance in which the player, unable to control his deepest impulses, reached an otherworldly-or more precisely, 'inworldly'-state of mind. He became fused with the instrument, imploding all its soundscaping possibilities through his own physical expression, oblivious to social etiquette and moderate containment of sentiment. One of Goffin's most celebrated passages describing this effect is his portrayal of Louis Armstrong: "Louis possesses the great gift which permits him almost automatically to enter into a trance and then to express his sensibility by means of his instrument" (Qtd. Gioia, 1988: 30). Goffin later adds that "I know of no white musician who is able to forget himself, to create his own atmosphere, and to whip himself up into a state of complete frenzy" (Qtd. Gioia, 1988: 30).

Surely the hyperbolic sexualization and animalization of blacks had been prevalent in the white supremacist discourse long before Darwin and before the avantgardes; sixteenth, seventeenth and eighteenth-century accounts of the middle passage attest to the institutionalization of these perceptions through slavery. But Darwinism provided a new prism that white western culture could no longer negate, at least scientifically. In order to rescind evolutionism, distance had to be marked discursively and socially; the high art / folk culture antinomy constituted the artillery to combat allegations on racial similitude and to taxonomically refute the existence of that otherness within. For white supremacists, otherness needed to remain without, and it needed to retain its symbolic and connotative qualities for them to identify and not acknowledge within themselves. Race, in other words, was a vibrant mythical construct aiming to eternalize and personify otherness, and jazz, that music that attracted the white rebellious youth was to be irreparably stigmatized with primitivism. At the same time, avant-garde artists were prone to consecrate the intricacies of this supposed unison of humanity through races, hence propelling the music as the symbol of historical genesis, present, and futurism. In David Meltzer's words, “jazz has been celebrated and damned for the same reasons: for possessing the body, for restoring a person momentarily to a state of noble and innocent savagery, for inflaming sexual jungle 
fantasies, [and] for being the absolute acme of all that's new and modern" (1993: 21 22).

Concomitant to the avant-gardes was the modernist wave of anthropology. In the late 1910s and 1920s, the prioritization of the study of ritual in ethnography was in its height with the works of Sir James Frazer (the abridged version of The Golden Bough was published in 1922), Franz Boas, whose extensive career resulted in multiple significant studies such as The Mind of Primitive Man (1911) and Primitive Art (1927), Lucien Lévy-Bruhl's Primitive Mentality (1922) and The Soul of the Primitive (1927), and Bronislaw Malinowski's "Magic, Science and Religion" (1925) and "Myth in Primitive Psychology" (1926). Theoretical and conclusive differences aside, these scholars sought to establish the relationship between mythologies (in the sense of a collection of narratives, usually of an oral character), and ritualistic enactments of them, either through magic, through practices based on animistic and totemic principles, or through customs based on taboo. As the examinations of ritual became a leading approach to negotiate western man's relationship and connection to the 'other,' white writers adorned their conjectures with summons of wild West African rites, Congo Square dance routines to the polyrhythm of the drums, or collective customs held in the slave plantations of the South. A jazz or a blues performance was sure to evoke these settings in the minds of whites within earshot.

Formalistic arrangements and the content of the music could equally be subjected to highbrow and avant-garde understandings of primitiveness. In terms of form, soundscapes of the Negro past were reproduced in the blues: from the callresponse patterns of the field hollers and spirituals to the inflexions, whoops, cries, howls, and shouts that had awed and mesmerized slave owners throughout the last centuries, these practices were common in the recordings of race records. Embellishments also included onomatopoeic sounds reminiscent of the rural environment of the South: from imitations of screech owls, whose distinct cry was traditionally interpreted by slaves as an omen of death, to rhythmic reproductions of kinesthetic exhaling used to maintain the beat in work songs, and sometimes evocative howls of the hounds released to hunt down the runaway slave. These stylistic devices were viewed as metonymical remains of ritual customs of Negro culture of the antebellum South. In terms of content, primitive and classical blues lyrics were filled with behavioral attitudes apparently unmediated by reason, morality, or even common sense. Lyrics on jealousy, beatings, whippings, murder, and unfaithfulness represented the dark side of love and sex. The moans and groans accompanying the lyrical plot produced dramatizing effects that recalled the imitative and homeopathic features of rituals described by ethnographers, whereupon a feeling was magically exorcised or controlled through a socially established physical enactment that signified upon the moment of crisis. Other times, the singer could praise his or her lover and boast publicly about the sexual and emotional fulfillment he or she felt. Sexual metaphors referring to genitalia, prowess, and to how one's partner performs in bed were a commonality within the blues discourse, and they were enriched by borrowing terms from other semantic fields to expand the allegory. Vocabulary based on food, animals, or the 
automobile was frequently exploited, and its connotations were not lost on the white race-record collectors. The thematic content was deemed as primitive in itself for its presentation of bestial human urges, from roaring sexual cravings to the physical pain of hunger, from the desolation of poverty to murderous and suicidal resolutions. Rather than interpreting these features from a contextual point of intersection where the collectivity can retain its historical identity, the tendency of whites seemed to be of an additive structure. These components, whether appealing to ritual, to an instinct unmediated by reason, or to a humanity past, appeared enumerated, counted one on top of the other as if searching for a quantitative result that might explain the qualitative elements of the aesthetic. Categories of identity do not meet at a junction, and therefore they cannot accurately respond to a causal history.

\section{II.}

Let us now consider the prime rhetorical figures functioning in white jazz writing within this context where primitiveness was central to the humanities and sciences. Our material for analysis spans from the mid-1910s to the mid-1940s, just before bebop emerged as the movement that would truly establish jazz within the high art frame.

In Mythologies, Barthes provided a semiologic model to interpret contemporary layers of ideology and their hierarchical, suppressive qualities. Stepping beyond ethnology, in which a recompilation of oral narratives and rituals is the starting point of mythography, Barthes turns to the notion of myth as speech to address how the contingencies of political fabrication manipulate the message whilst avoiding the identification and classification of bourgeois thinking. According to Barthes, myth is not an object, nor a concept, nor an idea; it is a mode of signification used by the hegemonic culture to distort the meaning of received concepts. The final intentionality of myth is the deprivation of the concept's history, so as to supply it with an alternative meaning that may better adjust itself to the interests of bourgeois morality. Barthes refers to this process as the naturalization of history, by which the dominant class appropriates the oppressed one, imperiously suffusing their supremacist ideology and providing static, eternal images that adequately fit within bourgeois hierarchies. In our case, the bourgeoisie is embodied by the European and white American middle and upper class, and it is their way of dealing and manipulating racial relations at a time of segregation which is responsible for the vast amount of mythical speech affecting the most popular black aesthetic at the time, jazz and the blues. Whether consciously or not, the primitivist myth, that is, the speech that naturalizes jazz as the untainted product of savagery, or, in its milder form, of instinct and intuition, was an effective operation that ultimately led to the act of dispossession, the depriving of an explicative, causal history in connection with the black race's artistic expression. White jazz critics deformed the relationship between the musician and his instrument, and by extension, between the agent and the significance of the idiom. Jazz as a signifier signified negritude, and negritude in itself was a conglomeration of stereotypes and images soaked in exoticism and static atavisms. 
Bourgeois mystification achieves this naturalization of history by way of a series of rhetorical devices. Barthes does not prioritize the importance of any of these figures; rather, they tend to appear distributed throughout the average bourgeois discourse. The reader will soon find that these devices easily overlap, and that more than one figure can often be distinguished within certain statements or fragments of the selected texts. For this reason, it should be kept in mind that no rhetorical method prevails over any of the others, and that they should be viewed as a matrix of operative forms of mythical speech. To better introduce the reader within these mystifying forms, we shall begin by pointing out how race and jazz are inextricably linked. The problem can be understood as one of tautologies and statements of fact, which are two of the most similar rhetorical devices used by the bourgeoisie. Tautology "consists in defining like by like" and "takes refuge behind the argument of authority" (Barthes, 1972: 153). It relates to statements of fact in that it acquires the status of a maxim; while tautologies avoid explanation precisely because they are built on the illusion of a rationality that is in fact absent, statements of fact rest upon the foundation of common sense. Given the multiple mystified layers functioning within the social construct of the black race (Gilroy, 2002), allegations of savagery, brutishness, and nobility can practically be understood at a tautological level of repetitive equivalences. The implication is that "blackness is savagery" and "savagery is blackness"; "white taste is intellectually justified" and "intellect exemplifies white virtue"; "Negroes are instinctive" and "instinct is the prime character of the Negro race," etc. The resulting discursive texture is one sustained on the grounds of the longevity of such beliefs. These claims strengthen the pillars of a set of shared values reinforced by tradition; tautologies and statements of fact elude counterarguments because it is in their nature to suggest that it would be nonsensical and unreasonable to question their enunciation. Not only do questions cease to be asked, but more importantly, the moral claim contained within the tautology or the statement does not induce to challenge. Linguistically and morally, the claim becomes apothegmatic, of a pseudo-proverbial quality. George Fredrickson lists a series of common-held assumptions about the black race that were prevalent from the 1830s until practically the surge of the Civil Rights Movement. The list can be reduced to two main ideas, which are that "blacks are physically, intellectually, and temperamentally different from whites" and that "blacks are also inferior to whites in at least some of the fundamental qualities wherein the races differ, especially in intelligence" (Fredrickson, 1987: 321). As will soon become clear, most of the following rhetorical figures can be reduced to the principles of these maxims, whereupon the black / white value dualism can always find its ultimate justification.

Let us now view the figure of inoculation, which consists in "admitting the accidental evil of a class-bound institution the better to conceal its principal evil" (Barthes, 1972: 150). Functioning as a sort of linguistic red herring that can better conceal the politics of the bourgeoisie, this device appears all the more prevalent in texts arousing the noble savage, sambo-like image. Hugues Panassié was especially fond of presenting the oppressive conditions under which the jazz spirit was molded. In The Real Jazz (1942), he wrote that: 
As a consequence to the ostracism to which, in the United States, the whites had subjected the colored people, the Negroes lived apart, among themselves, and did not participate in the prevailing cultural stream, but formed a primitive intellectual society of their own. The music which flowed from such a social grouping could not fail to present the characteristics of primitive music.

One of the most striking characteristics of primitive music is the absence of the line of demarcation between creation and execution, such as distinguishes European music of the twentieth century. In the beginning, before written music had been invented, a man seeking expression would sing or play what was on his mind. Creation and interpretation were as closely united as possible-were really one; the distinction between conception and interpretation with no direct connection was then unknown. (Panassié, 2005: 8)

For Panassié, there is no autonomy on the part of the Negro race if not in reactionary terms. He proclaims the marginalization of blacks as the origin of a ritualistic shaping, rightly accusing slaveocracy but developing a narrative where the oppressed has only very rudimentary tools from which to aesthetically express his situation. The immediacy between creation and interpretation suggests that the race had no other way of conceptualizing the social constrictions to which it was subjected other than the spontaneous transmission of deep anxieties. There is no rational process that may suggest that the collectivity was self-conscious about its art and that from very early on, there might have been a musicological, theoretical background that was progressively being refined and perfected. This child-like stage of an aesthetic cannot help but reflect an infantile state of mind on the part of the creators. Almost twenty years before Panassié published these statements, Gilbert Seldes presented in "Tojours Jazz" (1924) a similar appreciation of the unsophisticated creative method of blacks: "The negroes have given their response to the world with an exceptional naïveté, a directness of expression which has interested our minds as well as touched our emotions" he wrote; "they have shown comparatively little evidence of the functioning of their intelligence" (Seldes, 2004: 137). For Seldes, this was a setback that prevented him from truly accepting the idiom as an art, as much as he might have felt drawn to its exotic features. Spontaneity of expression, seductive as it was for the curious observer, did not answer to the standards of a qualified art form. In another passage he draws again on the binarism to ratify the heterogeneity of the disciplines:

I say the negro is not our salvation because with all my feeling for what he instinctively offers, for his desirable indifference to our set of conventions about emotional decency, I am on the side of civilization. To anyone who inherits several thousand centuries of civilization, none of the things the negro offers can matter unless they are apprehended by the mind as well as by the body and the spirit. (Seldes, 2004: 136)

For Seldes, jazz required the intellectualization and refinement that only a white musician could offer. Hence his subsequent remark that Paul Whiteman was the savior of the idiom, and that he, along with other symphonic jazz composers and arrangers, could elevate the music to the standards of cultivated taste. Seldes suggests that despite its rootedness in the tragedy of peoples-"I have heard it said by those who have 
suffered much that [jazz] is the only native music worth listening to in America" (Seldes, 2004: 135)-the origin of the music does little to enhance its high art appeal, unless salvaged by the intellect of the white, civilized man. The viral demeanor of inoculation is that the acquiescence of an accidental evil (in this case slavery and segregation) remains a mere illusion. Oppression is presented matter-of-factly; slavery and marginalization are unavoidable topics when addressing African American aesthetics, but the writers may mask their treatment of it in many ways. The barbarism and atrocities inherent to a white supremacist social structure remain absent, as does the oppressor's moral decay resulting from such a system. Brutishness and savageness are still retained within the identity of the 'other,' and the best that the Negro can do to subdue such instincts is to become a noble-as opposed to a vicious-creature. This brings us to the acknowledgement of another accidental evil, which is the alleged corruption of morality through the machine and modern exploitative systems of the working class, the basis of capitalist dynamics. This evil, capital to the avant-gardes' retrogressive understanding of progress, launches the Rousseau-like noble savage into the context of the urban jungle. Oblivious to the perversion of politics and economy, the Negro in this way can be deemed as an image used "[to immunize] the contents of the collective imagination" (Barthes, 1972: 150). A very common depiction of the musician as a noble savage was one expressed by Ernest Ansermet in 1919, where again there is a failure to produce an image in which the black individual can appear as a rational human being.

The blues occurs when the Negro is sad, when he is far from his mammy, or his sweetheart. Then, he thinks of a preferred rhythm, and takes his trombone, or his violin, or his banjo, or his clarinet, or his drum, or else he sings, or simply dances. And on the chosen motif, he plumbs the depths of his imagination. This makes his sadness pass away-it is the blues. (Ansermet, 2004: 371)

The blues idiom, which would be propelled by Ralph Ellison and Albert Murray years later as an active contestation containing the same motifs that classical myths, Hemingway or Eliot expounded, appears here as the wailing of a creature that can neither master his destiny nor control his emotions, but can only faithfully reproduce the simple passions of his desires. The blues do not subdue the tragic sentiment; they are presented as a mere passive channel that will cheer the happy-go-lucky Negro up through the playful distraction of music. This diamond-in-the-rough stereotype was also to nostalgically attract the bourgeoisie for its symbolism of a lost era of purity, before the monstrous anxieties of the modern age drained the individual from the more essential matters of life. This damaged descendant of the noble savage appeared as a psychologically maimed figure, the quintessential victim of the evils of modernity. In 1934 Constant Lambert lamented that "in point of fact, jazz has long ago lost the simple gaiety and sadness of the charming savages to whom it owes its birth, and is now for the most part a reflection of the jagged nerves, sex repressions, inferiority complexes and general dreariness of the modern scene" (1993: 109). Lambert further acknowledged the noble savage's aesthetic role as a commodity for white audiences: "The Negro 
associations of jazz, the weary traveler, the comforting old mammy, the red-hot baby, have become a formula of expression only, as empty and convenient as the harlequin and the columbine of the nineteenth century" (1993: 109).

The method of inoculation results in the deprivation of history; black music is simplified to such an extent that there remains no room for the deeper narrative of the Negro past. What inoculation offers in return for its concession of accidental evils is a series of petrified images in which the need for an accurate history is annulled. Whether motivated by fascination or by revulsion, the black musician tended to appear in writing dominated by some savage instinct, frozen by its inability to become civilized, prostrated by the boundaries between the mainstream and the marginal. Nathaniel Mackey calls this taxonomical process the transition from 'verb' to 'noun,' where the latter stage represents the moment that the black race and its music become a white commodity:

"From verb to noun" means, on the aesthetic level, a less dynamic, less improvisatory, less blues-inflected music and, on the political level, a containment of the economic and social advances that might accrue to black artistic innovation. The domain of action and the ability to suggest by verb is closed off by the hypostasis, paralysis, and arrest suggested by noun. (1995: 77)

The transformation, therefore, consists in a process whereupon the objectified subject is denied any form of agency. Like a museum piece, the black musician retains all of his beauty or all of his ugliness in its fullest splendor. The irony lies in that despite the fact that jazz is a highly corporeal expression with a swinging, rhythmic drive forward, and that, as a music, its structure is a defying challenge to standard perceptions of time, movement is insulated within the rigid walls of the noun. Indeed, as we will shortly see, it is practically the standard in early white writing of jazz to describe the hectic rush of musicians, often through spasms, provocative dances, and vertiginous leaps from low to screeching tones, but these movements are not associated with the perfection of a tradition, nor with an artist's abilities to expose and reflect the intellect. Rather, they become eternalized through isolation from their proper history: every act of agency is conceived only in relation to what it means and how it relates to the white bourgeoisie. The function of jazz is no longer indebted to its own cultural past; jazz becomes a symbol of white perception of the Negro race, where motionlessness is necessary to capture its significance within the modern western world.

The transition from verb to noun deeply resembles the Barthean rhetoric devices of privation of history and identification. The first is summarized by Barthes as the method by which "myth deprives the object of which it speaks of all History" (1972: 151). The very act of inoculation through an evocation of slavery and segregation, because of the simplicity and distortion of its causal effects, is a gesture to the evaporation of history. "All that is left for one to do is to enjoy this beautiful object without wondering where it comes from" (1972: 151), Barthes claims. The simple narrative of the disheartened, yet merry black individual suffices for the white observer's interest. When writers were inspired to let their imagination loose, they 
summoned other faraway lands of exotic rituals that were just as petrified and dehistoricized as the black individual. George Antheil, for example, fathomed in 1934 that "the Negro music, like the Negro, has been living for a number of million years under terrible heat; Negro music has, in consequence, been baked as hard and as beautiful as a diamond" (2004: 391). It is this superficial search for a setting with which to associate the object that Barthes christens as the rhetoric of identification. According to Barthes, "the petit-bourgeois man is unable to imagine the Other," who is "a scandal which threatens his existence" (1972: 151). The strategy through which the bourgeoisie learns to deal with the 'other' and to know what to make of him is to paralyze him within the context that he knows, the place he has an image of, distorted as it may be:

How can one assimilate the Negro, the Russian? There is a figure for emergencies: exoticism. The Other becomes a pure object, a spectacle, a clown. Relegated to the confines of humanity, he no longer threatens the security of the home. The figure is chiefly petit-bourgeois. For, even if he is unable to experience the Other in himself, the bourgeois can at least imagine the place where he fits in. (Barthes, 1972: 152)

From early receptions of ragtime, the place where the Negro fit in was very clear to white listeners. A writer for The Musical Courier stated in 1900 that the aesthetic "in its wildness and savage exultation reeks of the forests of equatorial Africa" (Anonym. 2002: 61). More than fifteen years later, a tantalized Ivan Goll communicated his astonishment after witnessing the Revue Nègre in Berlin as follows:

Negroes dance with their senses. (While Europeans can only dance with their minds.) They dance with their legs, breasts, and bellies. This was the dance of the Egyptians, the whole of antiquity, the Orient. This is the dance of the Negroes. One can only envy them, for this is life, sun, primeval forests, the singing birds and the roar of a leopard, earth. They never dance naked: and yet, how naked is the dance! They have put on clothes only to show that clothes do not exist for them. (2004: 379)

Another critic, Paul Achard, summarized the Revue Nègre as a cluster of scenes from "stories of missionaries and travelers," "the Sudan," and "plantation landscapes" natural to "the Negro soul with its animal energies." These images were what was left of "the sad bygone time of slavery" (Qtd. Kear, 1996: 52, 53). Starring the alluring Josephine Baker, who from St. Louis and New York's Plantation Club had brought the Charleston, the Black Bottom, the Mess Around, and the Shimmy to Paris in 1925, the Revue Nègre shocked European audiences with its African motifs. For Goll and for Archard, the dances held onstage represented the ritualistic link between the race and the land. Dance was conceived as a practice by which Negroes expressed their rootedness to the wilderness in physical terms, and Baker's flawless rhythmic stomping, her frequently naked breasts and her (in)famous banana skirt embodied the remnants of these remote rites best. André Levinson reportedly described her as "an extraordinary creature of simian suppleness" and a "magnificent animality" (Qtd. Kraut 2003: 438). It was not only the stage props and the performers' visibly phallic costumes, but the 
dances themselves what perplexed the white public so much. Panassié argued that a clear characteristic of primitive music was that it was developed with the object of dancing for its ritualistic connotations (2005: 27). An anonymous writer for the Literary Digest claimed in 1917 that "the group that play for dancing, when colored, seem infected with the virus that they try to instill as a stimulus in others" (2002: 119).

Dancing particularly encouraged the white bourgeoisie to make allegations on involution. The notion of degeneracy had made significant impact in western culture through Darwinism and Max Nordau's Degeneration (1895), which predicted the end of civilization in the hands of naturalism and the decadent values of the aesthetes. The term indicated the transgression and subversion of the status quo by way of the perverse attitudes of the newer generations and non-European societies. Fear was especially aroused regarding sex, sodomy, and masturbation, and to indulge in such acts, particularly through interracial intercourse, would condemn civilization to reversion. Aversion to degeneracy was still a vital matter throughout the first decades of the twentieth century and inevitably germinated within the jazz discourse. In 1921, the highly opinionated Anne Shaw Faulkner raged against the music in an article poignantly called "Does Jazz Put the Sin in Syncopation?" claiming that "we have all been taught to believe that music soothes the savage beast, but we have never stopped to consider that an entirely different type of music might invoke savage instincts" (2002: 152). Bred in the atmosphere of the "half-crazed barbarian" of the "vilest deeds," the physiological effect of the music could only lead to the decay of moral virtue:

The human organism responds to musical vibrations. What instincts then are aroused in jazz? Certainly not the deeds of valor or marital courage, for all marches and patriotic hymns are of regular rhythm and simple harmony; decidedly not contentment or serenity, for the songs of home and the love of native land are all of the simplest melody and harmony with noticeably regular rhythm. Jazz disorganizes all regular laws and order; it stimulates to extreme deeds, to a breaking away from all rules and conventions; it is harmful and dangerous and its influence is wholly bad. (Faulkner, 2002: 153)

Faulkner does not explicitly describe what the alleged anarchic effects of jazz are exactly, nor does she have to. Degeneracy was implicitly bound to sexual obscenity, and it was understood by the highbrow readers of the Ladies' Home Journal, where the article was published, what Faulkner was implying. In other instances, apocalyptic visions of sexuality were overtly addressed. In 1928, Maxim Gorky wrote for Pravda an article titled "On the Music of the Gross" in which he describes the disturbing images suggested to him by a radio transmission of a jazz performance: "This insulting chaos of insanity pulses to a throbbing rhythm," he exhorts, "listening for a few minutes to these wails, one involuntarily imagines an orchestra of sexually-driven madmen conducted by a man-stallion brandishing a huge genital member" (1993: 111). Much less repelled but no less bewildered, Ansermet states that the performers of a Negro orchestra "are so entirely possessed by the music they play that they can't stop themselves from dancing inwardly," giving the impression "as if a great wind is passing over a forest or as if a door is suddenly opened on a wild orgy" (2004: 370). Antheil 
suggests that the novelty may lie on the fact that the American Negro's music "rhythmically... comes from the groins, the hips, and the sexual organs, and not from ... the breast, the brain, the ears and eyes of the white races" (2004: 391). The type of dancing that jazz incited was a provocation inciting man's lowest, most carnal instincts. A certain American biologist admonished that "better extinction than a decline to a savage past. Jazz is a signboard on the road that was travelled by Greece and Rome. Orgies of lewd dancing preceded the downfall of those nations" (Qtd. Leonard, 1962: 39). The hypersexualized, ritualistic components of jazz were reason enough to exclude it from the pantheon of high arts.

This brings us to yet another rhetorical device which Barthes calls "neithernorism," and which consists in "stating two opposites and balancing the one by the other so as to reject them both" (1972: 153). White anti-jazz advocates especially favored neither-norism when constructing a case against the consideration of the music as an art. Unable to find any novelty in the idiom, H.L. Mencken, for instance, was intrigued by the contagiousness of the jazz craze. In 1934 he wrote in The Baltimore Evening Sun the following:

There is something in [jazz]. But what, precisely? I can find nothing in what is currently offered. Its melodies all run to a pattern, and that pattern is crude and childish. Its rhythms are almost as bad; what is amusing in them is as old as Johan Sebastian Bach, and what is new is simply an elephantine hop, skip, and jump. Nor is there anything charming in jazz harmony, once it has been heard a couple of times. (Mencken, 1995: 416).

Mencken places his two basic opposites, the traditional and the innovative, none of which the idiom is able to satisfy. In order to qualify as a legitimate art form, the aesthetic at hand must mirror the causal and continuous relationship between the old and the new, which can be deciphered through a close inspection of analogical shifts. In other words, there must remain a likeness between the past and the modern, a likeness which may either be based on similarity or on reactionary forms of expression; either way the analogy remains because it reveals the causal order between past and present forms in such a way that the basic structure, that is, the accepted canon, follows a rigorous, rational development. In neither-norism, scales are essential; they are necessary instruments through which "reality is first reduced to analogues" and then "it is weighed" (Barthes, 1972: 153). Mencken weighs jazz on the scale, where one end measures tradition and the other modernization. The result is a presentation of jazz as an amateurish inversion of these categories: where there should be inventiveness there is only a coarse imitation of classical standards; what jazz supplies to modern expression, furthermore, is an infantilizing of what had taken centuries of musical evolution to perfect. The "hop, skip, and jump" is, in a way, an insult not only to the past, but to the taste for aesthetic appreciation that any given slightly cultivated individual is bound to have. The merging of childishness, animalization, and aesthetic miscegenation does not seem accidental: Mencken meticulously chooses the term "elephantine," which initially refers to the clumsy stomping of elephants, a symbol of Africa in itself, and could also suggest the original lands of the music through its evocation of Elephantine Island, in 
the southeast of Egypt. Mencken's insidious allusion to African motifs does not result in exotic seductiveness, as was the case of many other writers, but circles around the pervading notion of puerile crudeness. In the end, there is nothing about the basic measurable parameters (melody, rhythm, harmony) which dignifies jazz; none of these criterions can adequately function within the imaginary scale because of their subversion of the very considerations that render the weighing worthwhile. Barthes claims that this is the natural culmination of the neither-nor technique; in the end, by way of this "magical behavior," "both parties are dismissed because it is embarrassing to choose between them" (Barthes, 1972: 153). Jazz loses all its arguments to make a case for itself: it is neither traditional nor modernistic, and hence it is inapt for becoming a high art.

Mencken's cunning declamation, published only a year before swing officially revolutionized the music marketing industry, echoed more overt usages of neithernorisms that had marked white jazz writing for a decade. In 1925, Cecil Austin claimed that "the hall mark of all great art is its honesty and sincerity. But jazz is neither ideal nor pure, neither is it sincere. It is faithful to nothing, an 'art' without parents and without relations" (2004: 147). That jazz was an orphan of the arts was also the argument made by Clive Bell, who, like Mencken, played with the idea of the music as a childish expression. In 1921 he published the well-known essay "Plus de Jazz!" in New Republic, where he wrongfully predicted the decline of the idiom, and where he described its features as follows:

Impudence is its essence-impudence in quite natural and legitimate revolt against Nobility and Beauty... Its fears and dislikes-for instance its horror of the Noble and the Beautiful- are childish; and so is its way of expressing them. Not by irony and sarcasm, but by jeers and grimaces does Jazz mark its antipathies. Irony and wit are for the grownups. Jazz dislikes them as much as it dislikes Nobility and Beauty. They are products of the cultivated intellect, and Jazz cannot away with intellect or culture. Niggers can be admired artists without any gift more singular than high spirits; so why drag in the intellect? (Bell, 2001: 41)

The opposites are again manifest: neither does jazz have the nobility and beauty characteristic of the arts nor the irony and wit that mark the turning point towards a new respectable period in the evolution of any aesthetic. The scales adopt a more visible presence through the use of comparatives of equality ('as much... as'), where grammatical imperatives naturally seek a balance. In the end, the scale is again dismissed not because of its inability to measure in accordance with other standards, in which case the rhetorical figure would cease to perform its bourgeois function, but because the very material that is being weighed is faulty. Hereon, the agent of mythical speech embraces the actual intentionality of the figure, for "one not only needs to choose, but only to endorse" (Barthes, 1972: 153). Furthermore, jazz responds in "horror" and with "jeers and grimaces" to the previously mentioned western standards, adding, in Bell's view, insult to injury. These words revolve around the overall notion of impudence, projecting an image of the highest insolence and impulsiveness that are 
idiosyncratic of the social construct of blacks. Unlike in Mencken's more suggestive case, the opposites here become overtly racialized, and the tautologies and statements of fact between whiteness and intellect and blackness and simplicity become transparent.

The imaginary motif of the scale is helpful to comprehend the final rhetorical figure, which Barthes calls 'the quantification of quality' and which is latent in practically all the other mystifying methods. I mentioned in the beginning of this analysis that the rhetorical figures tend to overlap, and that tautologies and statements of fact could be identified within the other devices when considering the stereotypical images that race constructs involve. As Barthes asserts, all the figures can be fundamentally reduced to the categories of "the Essences and Scales" (1972: 155), with the overall aim of deliberately depriving the mystified concept or object from its history and presenting a naturalized, apparently eternal image as surrogate. I also mentioned that white writers tended to represent jazz through additive structures where the music's features where successively enumerated without reference to a tangential point of intersection in which categories could more successfully provide a faithful construct of black art, and by extension, black identity. This additive tendency is crucial to comprehend Mackey's description of the paralysis of the black musician as a noun, through which he becomes a mere conglomeration of bourgeois values and stereotypes. The quantification of quality answers to this strategy: as the construct of the Negro race is reduced to a series of maxims, that is, it is reduced to naturalized essences, myth quantifies by placing these essences one on top of the other within the discourse. We have seen several examples of this throughout the previous citations, where the virtual past of Negroes is added to the savageness of the race, which is added to the sexual indecency of its character, which is added to jazz's illegitimate nature as a high art, etc. The only result to the additive structure, to the quantification of qualities which are themselves reduced to essences, is the hopelessly circular, repetitive pattern that the essences follow, for each of them signifies to other essences, which through tautology and statement of fact signify to other essences and back to the signifier that had initially signified upon them. There is no cardinal essence within the structure just like there is no final one: the mystifying game is always one where the metalinguistic process of signification appears homogeneously, for such is the only way through which naturalization can be effective.

This article has made an overview of how the rhetorical techniques described by Barthes function within early white jazz discourses in the hopes of contributing further insights regarding the dynamics of primitivism in the first decades of jazz development. By viewing the mythopoeic proclivities of dominant culture and deciphering their intrinsic linguistic and metalinguistic structures, we may better comprehend how an aesthetic which appears threatening to the dominating culture can be subdued through ideological colonization. In the same way that myth simplifies and distorts the history and meaning of an aesthetic in order to appropriate its function and confine it to a categorical space in supremacist hierarchies, scholars need to avoid interpreting this act of colonization as a mere social agreement based on a superficial exploitation of 
images. It is in the syntactic connections underlying such images where we may better comprehend not only the relationship between ideology and the grammar of the mind, but the intentionality followed by the hegemonic race in its desire to sustain and eternalize its power. This order of things, perceived by the bourgeoisie as natural, follows a carefully calculated hierarchy, the rigidity of which is governed by myth. Myth assures that both the negative and the exotic maintain a fixed position within the hierarchy, and the spirit of jazz history asks that we not forget this original paternalistic outlook of America on African American music. As Josephine Baker once declared, "the white imagination sure is something when it comes to blacks" (Qtd. Rose, 1989: $81)$.

\section{References}

Anonym. (2002) (Literary Digest, Aug. 1919): “The Appeal of the Primitive Jazz." In K. Koenig, ed., Jazz in Print (1856-1929). An Anthology of Selected Early Readings in Jazz History. New York: Pendragon, 119-120.

Anonym. (2002) (The Musical Courier, May 1900): "Ragtime Communication.” In K. Koenig, ed., Jazz in Print (1856-1929). An Anthology of Selected Early Readings in Jazz History. New York: Pendragon, 60-61.

Ansermet, Ernest (2004) (1919): “On a Negro Orchestra.” In D. Albright, ed., Modernism and Music. An Anthology of Sources. Chicago: The University of Chicago Press, 368-373.

Antheil, George (2004) (1919): "The Negro on the Spiral, or A Method of Negro Music." In D. Albright, ed., Modernism and Music. An Anthology of Sources. Chicago: The University of Chicago Press, 390-398.

Appel Jr., Alfred (2002): Jazz Modernism. New Haven: Yale University Press.

Apollinaire, Guillaume (2004) (1913): The Cubist Painters. Trans. Peter Read. Berkeley: University of California Press.

Austin, Cecil. (2004) (1925): “Jazz.” In L. Porter, ed., Jazz: A Century of Change-Readings and New Essays. Belmont, California: Wadsworth, 146-147.

Barthes, Roland (1972) (1957): Mythologies. Trans. Annette Lavers. New York: Hill and Wang.

Bell, Clive (2001) (1921): "Plus de Jazz!" In A. Clark, ed., Riffs and Choruses. A New Jazz Anthology. New York: Continuum International, 40-42.

Faulkner, Anne Shaw (2002) (1921): “Does Jazz Put the Sin in Syncopation?" In K. Koenig, Jazz in Print (1856-1929). An Anthology of Selected Early Readings in Jazz History. New York: Pendragon, 152-154.

Fredrikson, George M. (1987): The Black Image in the White Mind. The Debate on AfroAmerican Character and Destiny, 1817-1914. Middletown, Connecticut: Wesleyan University Press.

Gennari, John (1991): "Jazz Criticism: Its Development and Ideologies." Black American Literature Forum 25(3): 449-523.

Gilroy, Paul (2002) (1993): The Black Atlantic. London: Verso.

Gioia, Ted (1988): The Imperfect Art. Reflections on Jazz and Modern Culture. New York: Oxford University Press. 
Goll, Ivan (2004) (1926): “The Negroes are Conquering Europe." In D. Albright, ed., Modernism and Music. An Anthology of Sources. Chicago: The University of Chicago Press, 378-380.

Gorky, Maxim (1993) (1928): “On the Music of the Gross.” In D. Meltzer, ed., Reading Jazz. San Francisco: Mercury House, 111-112.

Kear, Jon (1996): "Vénus noire: Josephine Baker and the Parisian Music-Hall." In M. Sherringham, ed., Parisian Fields. London: Reaktion Books, 46-70.

Kraut, Anthea (2003): "Between Primitivism and Diaspora: The Dance Performances of Josephine Baker, Zora Neale Hurston, and Katherine Dunham.” Theatre Journal 55(3): 433-450.

Lambert, Constant (1993) (1934): “The Spirit of Jazz.” In D. Meltzer, ed., Reading Jazz. San Francisco: Mercury House, 106-111.

Leonard, Neil (1962): Jazz and the White Americans. Chicago: The University of Chicago Press.

Mackey, Nathaniel (1995): “Other: From Noun to Verb.” In K. Gabbard, ed., Jazz Among the Discourses. Durham: Duke University Press, 76-99.

Meltzer, David (1993): Reading Jazz. Ed. David Meltzer. San Francisco: Mercury House.

Mencken, H.L. (1995): In Teachout, Terry, ed., A Second Mencken Chrestomathy. New York: Alfred A. Knopf.

Panassié, Hugues (2005) (1942): The Real Jazz. Whitefish, Montana: Kessinger Publishing.

Rose, Phyllis (1989): Jazz Cleopatra: Josephine Baker in Her Time. New York: Doubleday Books.

Sandke, Randall (2010): Where the Dark and the Light Folks Meet. Race and Mythology, Politics, and the Business of Jazz. Plymouth, UK: Scarecrow Press.

Seldes, Gilbert (2004) (1924): “Tojours Jazz.” In L. Porter, ed., Jazz: A Century of Change Readings and New Essays. Belmont, California: Wadsworth, 134-140. 